\title{
Os Proprietários de Escravos e a Estrutura da Posse na Antiga Freguesia de São Simão, 1835
}

\author{
Luciana Suarez Lopes \\ Professora - Departamento de Economia (FEA/USP) \\ Endereço para contato: Av. Prof. Luciano Gualberto, 908 - Cid. Universitária - CEP: 05508-010 \\ E-mail: Islopes@usp.br
}

Recebido em 14 de julho de 2010. Aceito em 26 de março de 2012.

\begin{abstract}
Resumo
Este artigo estuda a estrutura da posse de escravos em São Simão, localidade do nordeste paulista, utilizando a lista nominativa de 1835. O objetivo principal é analisar a estrutura da posse de escravos na região pouco antes da chegada do café, pois, ao que tudo indica, a estrutura produtiva formada nesse período teria contribuído para o rápido desenvolvimento da cultura cafeeira durante a segunda metade do século XIX. Destaca-se o caso de Ribeirão Preto, localidade desmembrada de São Simão nos primeiros anos da década de 1870, que chegou a ser a maior produtora de café do Estado de São Paulo.
\end{abstract}

\section{Palavras-Chave}

cafeicultura, escravidão, São Simão, Ribeirão Preto

\begin{abstract}
This paper analyses the slaveholding structure in São Simão, a town northeast of São Paulo, using the manuscript known as lista nominativa of 1835 . The objective is to analyze the structure of ownership of slaves in the region before the arrival of coffee. Apparently, the production structure formed in this period gave conditions, among other factors, for the rapid development of coffee cultivation during the second half of the nineteenth century, especially in the town of Ribeirão Preto, separated from São Simão in the early years of the 1870s. Ribeirão Preto, in the last decade of the nineteenth century, became one of the largest producers of coffee in the State of Sao Paulo.
\end{abstract}

\section{Keywords}

coffee, slavery, São Simão, Ribeirão Preto

\section{JEL Classification}

N36 - Economic History: Labor and Consumers, Demography, Education, Health, Income and Wealth: Latin America, Caribbean

\footnotetext{
- Essa pesquisa contou com o apoio financeiro da FAPESP - Fundação de Amparo à Pesquisa
} do Estado de São Paulo. 


\section{Introdução}

A região de São Simão experimentou, durante as décadas finais do século XIX, um rápido desenvolvimento motivado pela chegada da cultura cafeeira. A partir do momento em que foi introduzida na região, a cafeicultura desenvolveu-se aceleradamente, absorvendo terras, capital e mão de obra. Nos primórdios, a abertura e/ou expansão das fazendas produtoras se deu por meio da utilização combinada do trabalho escravo e do trabalho assalariado, tanto de trabalhadores nacionais como de imigrantes. Não se pode negar que uma parcela desse sucesso relaciona-se com a estrutura produtiva já existente na região, desbravada ainda durante os séculos XVII e XVIII. O processo de ocupação foi acelerado pela decadência das minas e a chegada dos chamados entrantes mineiros. Destacam-se, neste contexto, as atividades de criação de gado e agricultura de subsistência, responsáveis pela manutenção do contingente cativo aproveitado posteriormente pelo café. As localidades de São Simão e Ribeirão Preto tornaram-se prósperas produtoras de café. Em especial esta última, desmembrada de São Simão no início da década de 1870, que chegou a ser a maior produtora de café do Estado de São Paulo no final do século XIX.

A região considerada pelo presente estudo é aquela da freguesia e posterior vila de São Simão, localizada a oeste do Caminho dos Goiases. Parte do antigo sertão desconhecido, a região de São Simão localizava-se entre os rios Pardo e Mogi-Guaçu, próxima das antigas localidades de Casa Branca, Batatais e Franca.

Originalmente, a freguesia de São Simão, criada em 1842, pertencia à localidade de Casa Branca, da qual foi desmembrada em 1865. ${ }^{1} \mathrm{~A}$ freguesia de Casa Branca, por sua vez, foi criada em 1814 no território da antiga vila de Mogi-Mirim, da qual foi desmembrada em 1841. Este esclarecimento se faz necessário, pois são escassos os dados disponíveis para São Simão durante a primeira metade do século XIX. Sendo assim, em alguns momentos do texto serão dadas informações sobre as localidades de Casa Branca ou Mogi-Mirim como uma proxy

1 O termo freguesia era utilizado para designar o que atualmente é conhecido como distrito. Já o termo vila equivale ao atual município. O processo que formava uma nova localidade geralmente começava quando os moradores de um núcleo populacional decidiam doar terras à igreja com o objetivo de se construir uma capela. Quando o patrimônio eclesiástico era formado e a igreja construída, o núcleo populacional ganhava o status de freguesia. Com o passar do tempo e o adensamento populacional, a freguesia era elevada à categoria de vila, ocorrendo o desmembramento territorial do município ao qual a freguesia era subordinada. 
das características de São Simão. As localidades de Casa Branca, Mogi-Mirim e São Simão estão ao sul do rio Pardo. Ao norte do rio Pardo estão as localidades de Batatais e Franca. A antiga Vila Franca do Imperador foi desmembrada de Mogi-Mirim em 1821. Já a vila de Batatais foi desmembrada da de Franca em 1839. O Mapa 1 traz o território aproximado das então vilas de Casa Branca, Batatais e Franca, assim como sua localização na província paulista. No mapa não aparece destacado o território de São Simão, mas apenas um indicativo de sua localização, no triângulo formado pelos rios MogiGuaçu e Pardo.

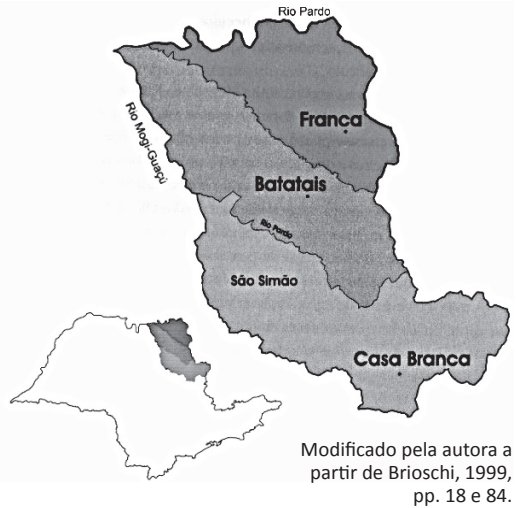

Mapa 1 - Localidades do Nordeste Paulista (Franca, Batatais e Casa Branca, meados do século XIX)

O presente artigo tem como objetivo analisar a estrutura produtiva existente em São Simão antes da chegada da cafeicultura, considerando ter sido essa estrutura importante para o sucesso posterior da atividade cafeeira. É certo que o sucesso da economia cafeeira na região dependeu também da adequação de suas terras ao cafeeiro; da chegada oportuna da ferrovia, da existência de mecanismos de financiamento; e da expansão adequada da mão de obra. Contudo, o desbravamento da região, a ocupação primitiva de suas terras, a configuração da estrutura fundiária, a organização administrativa eclesiástica e também secular, tendo acontecido em período anterior ao da chegada do café, contribuíram para que a atividade cafeeira e os demais fatores mencionados anteriormente encontrassem uma estrutura produtiva estável sobre a qual pudessem se instalar e desenvolver. 
Dessa maneira, a fim de caracterizar a economia pré-cafeeira em São Simão, serão utilizados principalmente os dados da lista nominativa de 1835. Como fontes documentais adicionais, são utilizadas as listas de qualificação de votantes e o conjunto de inventários post-mortem das localidades de São Simão e Ribeirão Preto. Na primeira seção, são analisados o desbravamento e a ocupação do nordeste paulista. Em seguida, analisar-se-á a antiga freguesia de São Simão, destacando-se os aspectos econômicos e a estrutura da posse de escravos. Por fim, será considerada a introdução da cultura cafeeira na localidade, com ênfase nos pioneiros da cafeicultura em São Simão e na região que viria a se tornar a vila de Ribeirão Preto.

Maria Thereza Schorer Petrone, em estudo publicado originalmente em 1968, demonstrou a importância da cultura de cana-de-açúcar na gestação da infraestrutura necessária ao posterior desenvolvimento da cultura cafeeira em São Paulo.

Foi ela responsável pela modificação completa do panorama econômico e social da região, criando uma infra-estrutura necessária ao desenvolvimento do comércio exterior e tornando possivel, mais tarde, o rápido crescimento dos cafezais no hinterland de Santos. Com sua expansão geográfica e com o acúmulo de capitais dela derivado, preparou-se São Paulo para desenvolver outro ramo de riqueza. (Petrone, 1968, p. 223)

Na região de São Simão, a cultura da cana-de-açúcar, apesar de presente, não era a responsável pelo dinamismo econômico da região. A criação de gado é que desempenhou esse papel. Foi ela a responsável pelo desbravamento e pela ocupação da região, e foi para atender as suas necessidades que se criou uma rede de comunicação entre a região de São Simão e os principais centros do comércio regional. Ademais, a atividade criatória desenvolvida na região permitiu, além de certa acumulação de capitais, a manutenção de um razoável contingente de cativos e de trabalhadores livres, rapidamente absorvidos pela cafeicultura em momento posterior. 


\section{Os Entrantes Mineiros e a Ocupação do Nordeste Paulista}

Durante os séculos XVII e XVIII, a ocupação do sertão paulista foi motivada pelo constante movimento de viajantes e tropeiros pelo conhecido Caminho do Anhanguera, ou Caminho dos Goiases. Os pousos estabelecidos para dar apoio aos viajantes acabaram por se transformar em núcleos populacionais, arraiais, freguesias e vilas. $\mathrm{Na}$ primeira metade do século XVIII, a descoberta do ouro em Goiás fez intensificar o trânsito nesse caminho, acelerando o povoamento da região. Com a decadência das minas goianas e a diminuição do fluxo de pessoas, diversos pousos entraram em decadência. Várias áreas até então ocupadas ficaram abandonadas, e relatos de viajantes que transitaram pelo interior do país durante a primeira metade do século XIX mostram que nesse período o nordeste paulista ainda possuía muitas áreas desabitadas. Em especial a região que ficava a oeste do caminho, pois

Do atual município de São Simão até a confluência dos rios Moji e Pardo, de Luis Antônio a Ribeirão Preto, a vegetação mais densa afastava os primeiros moradores, com sua técnica rudimentar de ocupação e exploração da terra. O oeste do Caminho de Goiás era representado, nos mapas da época, como um espaço aberto, denominado "sertão desconhecido". (Brioschi, 1999, p. 52)

Luiz D'Alincourt, português que percorreu o interior de São Paulo em 1818, conta em sua Memória sobre a Viagem do Porto de Santos à Cidade de Cuiabá que os territórios além de Campinas eram pouco povoados, dedicando-se, seus habitantes, ao cultivo de gêneros de subsistência, criação de gado e de pequenos animais. Em 1817, outro viajante, o naturalista francês Auguste de Saint-Hilaire, dá início a sua primeira jornada pela província paulista. Foram várias as localidades visitadas, tais como São Paulo, Itu, Mogi-Mirim, Campinas e Jundiaí. Entre Franca e Mogi-Mirim o naturalista percorreu cerca de quarenta léguas, aproximadamente 264 quilômetros, atravessando campos pouco acidentados, com pastagens e algumas flores. A historiografia mostra que durante a primeira metade do século XIX a região historicamente conhecida como Oeste Paulista recebeu um contingente considerável de migrantes mineiros, que trouxeram 
consigo a tradição pecuarista. Segundo Lucila Reis Brioschi, toda a região das antigas vilas de Casa Branca, Batatais e Franca recebeu esses chamados entrantes mineiros. Utilizando principalmente listas nominativas e registros paroquiais, a autora verificou que, apesar dos primeiros habitantes da região terem sido de origem paulista, as correntes migratórias do século XIX foram formadas predominantemente por mineiros. Em 1819, cerca três quartos dos habitantes do antigo Sertão do Rio Pardo eram de origem mineira. (Brioschi, 1995, p. 87)

[...] Entrando em terras paulistas pela vila de Jacuí ou pelo arraial do Desemboque, fundaram em um primeiro momento o arraial de Franca. Continuaram em direção sul e sudoeste, cruzando o Sapucaí-Mirim, estabelecendo núcleos de povoamento que deram origem a Santana dos Olhos d'Água e São José do Morro Agudo. Ultrapassando o rio Pardo, entraram no termo de Araraquara, na atual região de Barretos e mais ao sul ocuparam as terras do futuro município de Ribeirão Preto. (Brioschi, 1995, pp. 116-117)

A análise das listas nominativas de Casa Branca mostra que a porcentagem de chefes de fogo originários de Minas Gerais passou de $14,1 \%$ em 1815 para 34,3\% em 1829, sendo que na lista de 1827 essa porcentagem chegou a $51,7 \%$. (Lages, 1996, pp. 119-120)

Com intenção de reproduzir em solos paulistas as atividades de sua província natal, os migrantes estabeleceram-se em áreas próprias tanto à agricultura como à pecuária, cultivando alimentos e criando gado. Saint-Hilaire, ao descrever as atividades desenvolvidas pelos habitantes da região entre Franca e Mogi-Mirim, relata que

Os fazendeiros aproveitam-se das excelentes pastagens que o lugar oferece, dedicando-se à criação de ovelhas e de numeroso gado, não negligenciando também a de porcos. Os mais ricos, [donos de fazendas ou de grandes propriedades - LSL] enviam as suas crias, por sua própria conta, à capital do Brasil, e os negociantes da Comarca de São João del Rei 
vão comprar nas próprias fazendas o gado dos criadores menos prósperos. Um grande número de bois da região é enviado também para São Paulo, onde são usados no trabalho dos engenhos de açúcar. Ali, a má qualidade das pastagens não tarda a fazer com que a maioria morra, o que força os seus proprietários a comprar outros. Alguns anos antes da época de minha viagem, os bois não valiam ali mais do que 3.000 réis; em 1819 os negociantes compravam-nos até por 5.000. (Saint-Hilaire, 1976, pp. 92-93)

A importância dessas atividades na primeira metade do século XIX, em especial da atividade criatória, pode ser comprovada observando-se os dados apresentados pelo marechal Daniel Pedro Müller, reproduzidos na Tabela 1 . Deles é possível inferir que os dois maiores rebanhos da antiga província estavam localizados justamente na região nordeste da antiga Província, o maior deles na grande vila de Mogi-Mirim e o segundo na vila de Franca.

Tabela 1 - Produção de algumas Localidades Paulistas (Mogi-Mirim, Campinas e Franca, 1836)

\begin{tabular}{llccc}
\hline Produtos & Unidade & Mogi-Mirim & Campinas & Franca \\
\hline Café & Arrobas & 610 & 8.081 & 211 \\
Açúcar & Arrobas & 40.520 & 158.447 & 272 \\
Aguardente & Canadas & 2.312 & 7.399 & 337 \\
Arroz & Alqueires & 8.668 & 3.672 & 2.111 \\
Farinha de mandioca & Alqueires & - & 952 & 3.893 \\
Feijão & Alqueires & 12.558 & 21.015 & - \\
Milho & Alqueires & 354.707 & 96.786 & 138.632 \\
Fumo & Arrobas & 1.850 & 358 & 311 \\
Algodão em rama & Arrobas & 355 & - & - \\
Porcos & Unidades & 14.506 & 3.137 & 5.613 \\
Gado cavalar & Unidades & 1.574 & 221 & 353 \\
Gado muar & Unidades & 477 & 29 & 33 \\
Gado vaccum & Unidades & 2.313 & 687 & 1.817 \\
Gado lanígero & Unidades & 316 & 134 & 632 \\
Trigo & Alqueires & 16 & - & - \\
\hline Valor da Produção & & $308: 325 \$ 620$ & & $111: 882 \$ 920$ \\
\hline
\end{tabular}

Fonte: Müller, 1978, p. 126. 
Alguns estudos mais pontuais também confirmam a importância da pecuária na região. Segundo Leonel de Oliveira Soares, até meados do século XIX a pecuária era um dos setores mais dinâmicos da economia de Mogi-Mirim.

Dados de 1854 referentes aos anos de 1853, 1852 e 1851 indicaram uma exportação de 12 mil porcos, igual número de cavalos e seis mil cabeças de gado vacum. Esses números são de um período em que, conforme o autor, a lavoura de cana-de-açúcar estava cedendo espaço para a cultura cafeeira. Concomitantemente, a população de Mogi-Mirim também produzia gêneros de subsistência, sendo os mais comuns o feijão e o milho. A localidade de Mogi-Guaçu também tinha sua economia baseada na atividade criatória, e os produtos de subsistência estavam presentes em $77,2 \%$ dos fogos. Mais uma vez, as lavouras mais comuns eram o milho e o feijão. Poder-se-ia dizer que o quadro das atividades criatórias em Mogi-Guaçu não era diferente do verificado em Mogi-Mirim, exceto pelo fato de que seus rebanhos eram menores. (Soares, 2003, p. 20)

Em Batatais, importante pouso do antigo Caminho de Goiás, a principal atividade da população nas primeiras décadas do século XIX era também a criação de gado, em especial de gado vaccum. Além da criação as fazendas dedicavam-se também ao cultivo de gêneros alimentícios, tais como milho, algodão, feijão e o arroz, além de outros, tais como a mamona. (Garavazo, 2002, pp. 18-19)

$\mathrm{Na}$ antiga vila de Franca a criação também era a principal atividade da população durante a primeira metade do século XIX. Utilizando as informações disponíveis nos inventários post-mortem da localidade, Lélio Luiz de Oliveira verificou que dentre os diversos animais criados na região francana os bovinos constituíam maioria, representando $76,7 \%$ de todo o rebanho registrado. (Oliveira, 2003, p. 23)

Em 1835, a lista nominativa de São Simão informava que dos 150 moradores que declararam as atividades desenvolvidas em seus estabelecimentos, noventa e seis $(64,0 \%)$ criavam gado ou porcos. Em apenas uma ocasião o estabelecimento dedicava-se também à criação de equinos. A profusão de fazendas de criação pode ser explicada não só pela grande demanda pelos animais - amplamente utilizados como apoio na produção de açúcar e café - mas também pela facilidade de se iniciar uma criação. $\mathrm{O}$ investimento necessário para a 
formação de uma fazenda dedicada à pecuária era consideravelmente menor do que aquele exigido pela produção de açúcar ou café. Uma fazenda pequena podia começar com 200 ou 300 cabeças de gado, vinte e cinco ou trinta animais de trabalho e a mão de obra de quinze ou vinte homens. Por essa razão, a pecuária tornou-se uma atividade comum entre os menos abastados, transformando-se [...] refúgio dos colonos com recursos modestos, com freqüência adquiridos no exercício da profissão de vaqueiro. (Gorender, 1992, pp. 425-426)

Em Minas Gerais, essa agricultura de subsistência autônoma e especializada no abastecimento interno era comum. Sua principal função era o abastecimento das regiões mineradoras, já que a extração de ouro, ao contrário da grande lavoura, não permitia a produção conjunta de alimentos. Além disso, a proximidade com o Rio de Janeiro reforçou a especialização da região na produção de gêneros, fazendo com que a agricultura de subsistência mineira atingisse um nível bem mais elevado do que o existente nas demais regiões que se dedicavam à mesma atividade.

Dada a forte presença mineira na região de São Simão e sua significativa influência na formação da economia local, espera-se, ao analisar a questão da posse de escravos, encontrar uma estrutura compatível com as atividades agropastoris. É importante ressaltar que São Simão daria origem a uma das mais expressivas localidades produtoras de café da região historicamente conhecida como oeste paulista: Ribeirão Preto. A estrutura produtiva da qual o café se apropriou ao chegar à região de Ribeirão Preto é, em boa medida, reflexo da estrutura simonense que será analisada a seguir. O café chegaria poucos anos depois daquele no qual se efetuou o levantamento consignado na lista nominativa aqui estudada. A partir daí, a agricultura de subsistência e a criação de animais adequar-se-iam às necessidades da nova cultura dominante.

\section{A Propriedade Cativa na Antiga Freguesia de São Simão, 1835}

Infelizmente, são poucos os trabalhos que se dedicaram ao estudo da propriedade cativa no nordeste paulista, onde estava a região de São Simão. O pioneiro a tratar do tema foi Francisco Vidal Luna no artigo Características demográficas dos escravos de São Paulo, 1777 1829, publicado em 1992. Considerando as informações das listas 
nominativas de 1777, 1804 e 1829, o autor traçou o perfil populacional dos cativos paulistas, mostrando como o desenvolvimento da cafeicultura em São Paulo modificou as características da população mancípia durante o período. Ao todo, foram consideradas 25 localidades distribuídas pelas várias regiões de São Paulo, representando parcela considerável da população existente. ${ }^{2}$ (Luna, 1992)

Na região do nordeste paulista destaca-se a localidade de MogiMirim, que no período englobava o território da futura freguesia de São Simão. Em 1777, Mogi-Mirim contava então com apenas 164 cativos, com uma razão de sexo calculada em 107,6. Em 1804, graças ao desenvolvimento da economia açucareira, o número de cativos aumentou significativamente, passando para 826 , com razão de sexo também crescente, calculada em 128,2. Finalmente, em 1829, o grande salto: o número de cativos alcançou 2.215, sendo a razão de sexo calculada em 200,5! (Luna, 1992, p. 462) Segundo o autor, esse resultado deve-se ao desenvolvimento combinado de duas importantes atividades econômicas: o café e a produção de açúcar. ${ }^{3}$

Outros autores dedicaram-se ao estudo de áreas mais restritas. Dentre estes, destacam-se aqueles que escolheram tratar de localidades pertencentes ao nordeste paulista, Lélio Luiz de Oliveira, Juliana Garavazo e Renato Leite Marcondes.

Ao analisar a propriedade escrava e a hipótese de crescimento vegetativo dos escravos em Batatais, Renato Leite Marcondes e Juliana Garavazo encontraram uma estrutura de posse desigual, em certa medida concentrada e com ligeira predominância de cativos do sexo masculino. Na década de 1870, momento contemplado pelo estudo,

2 As localidades foram agrupadas em cinco regiões: o Vale do Paraíba (Areias, Cunha, Guaratinguetá, Jacareí, Lorena, Pindamonhangaba e S. Luiz Paraitinga); a Região da Capital (Atibaia, Cotia, Guarulhos, Mogi das Cruzes e São Paulo); o Oeste Paulista (Campinas, Itapeva, Itu, Jundiaí, Mogi-Mirim e Porto Feliz); o Caminho do Sul (Curitiba, Itapetininga e Sorocaba); e o Litoral (Cananeia, Iguape, Santos e São Sebastião). Apenas uma tabela, a Tabela 1, apresenta as localidades em separado. Como a localidade de São Simão, objeto do presente estudo, era uma região praticamente desabitada no período considerado pelo autor, acredita-se que a utilização de seus dados agrupados - região do Oeste Paulista - não constituiria uma boa estratégia. (Luna, 1992, p. 462)

3 Em artigo publicado em 1998, Luna retoma o estudo dessas 25 localidades. Ampliando suas análises, ele considera além de aspectos demográficos da população cativa, a dinâmica da população livre, as atividades econômicas, a estrutura da posse de escravos e as características demográficas dos proprietários de cativos. Novamente, as localidades são agrupadas em cinco grandes regióes, o Vale do Paraíba, a Região da Capital, o Oeste Paulista, o Caminho do Sul, e o Litoral. (Luna, 1998) Sobre os dados apresentados e sua utilização no presente trabalho, as observações finais da nota de rodapé anterior fazem-se mais uma vez pertinentes. 
a região de Batatais apresentava como principais atividades a criação de gado e a agricultura de subsistência. O café, principal produto de exportação da época, começava a ser cultivado em algumas propriedades, normalmente dividindo espaço com as atividades mais tradicionais. Em 1875, a comarca de Batatais contava com uma população de 11.255 habitantes, dos quais 2.160 cativos e 9.095 livres, sendo a porcentagem de escravos na sua população ligeiramente maior do que a encontrada para a província como um todo. Nesses cativos estava concentrada uma parcela considerável da riqueza de seus senhores. Localizando os inventários post-mortem de alguns desses proprietários, os autores verificaram que, em média, $17,6 \%$ da riqueza inventariada estava alocada em escravos. (Marcondes \& Garavazo, 2002, p. 5)

A Tabela 2 mostra em detalhes a estrutura da posse batataense. Os plantéis pequenos eram maioria e quase três quartos dos proprietários possuíam de um a quatro cativos. A posse média foi calculada em 4,9, sendo a posse média dos pequenos proprietários calculada em dois. O cálculo do índice de Gini, igual a 0,585, mostra que apesar da profusão de pequenos plantéis a propriedade se mostrava concentrada. A maior parte dos proprietários de escravos, 83,9\%, era do sexo masculino. Além de constituírem maioria, os homens proprietários também concentravam a maior parte da massa cativa. Os homens possuíam 2.151 (91,1\%) cativos e as mulheres $198(8,4 \%)$. A massa cativa restante era possuída por órfãos e herdeiros $(0,3 \%)$, além de haver alguns cativos possuídos em sociedade $(0,3 \%)$.

Trabalhando com os inventários dos proprietários encontrados na Classificação e com informações do Almanak da Província de São Paulo para 1873, Marcondes e Garavazo constataram que aproximadamente a metade dos proprietários dedicava-se à criação de gado, "atividade de maior importância para a cidade à época analisada", sendo que

[...] dos trinta e sete criadores de gado listados no Almanak, apenas três não constavam da Classificação. Adicionalmente, além dos criadores de gado vaccum exclusivamente, havia um número considerável de proprietários que criava suínos ou se dedicava à cultura de canade-açúcar ou café juntamente com a pecuária [...] (Marcondes \& Garavazo, 2002, p. 20) 
Franca, talvez a localidade mais dinâmica economicamente no nordeste paulista durante a primeira metade do século XIX, foi objeto de estudo de Lélio Luiz de Oliveira. Utilizando como fonte de dados 96 inventários post-mortem do Arquivo Histórico Municipal de Franca, Oliveira analisou a economia da antiga vila de Franca do Imperador em dois momentos no tempo. O primeiro deles, 18221830, mostra a antiga vila dominada pela criação de gado e seus desdobramentos - comércio de sal, manufatura do couro e produção de laticínios. O segundo período, 1875-1885, mostra a estrutura anterior um pouco influenciada pela chegada da cultura cafeeira.

Ao analisar a propriedade cativa, o autor encontrou entre seus inventariados uma alta porcentagem de proprietários, já que apenas 3,2\% dos inventários não arrolavam escravos, com uma média calculada em 4,8 cativos por proprietário.

Tabela 2 - Estrutura da Posse de Escravos segundo Faixas de Tamanho de Plantel (Batatais, 1875)

\begin{tabular}{lcccccc}
\hline \multirow{2}{*}{ FTP $^{(a)}$} & \multicolumn{3}{c}{ Proprietários } & \multicolumn{3}{c}{ Escravos } \\
\cline { 2 - 7 } & Número & $\%$ & \% Acumulada & Número & $\%$ & \% Acumulada \\
\hline 1 & 168 & 34,6 & 34,6 & 168 & 7,1 & 7,1 \\
2 a 4 & 193 & 39,8 & 74,4 & 541 & 22,9 & 30,0 \\
5 a 9 & 70 & 14,4 & 88,9 & 444 & 18,8 & 48,8 \\
10 a 19 & 34 & 7,0 & 95,9 & 439 & 18,6 & 67,4 \\
20 a 39 & 13 & 2,7 & 98,6 & 365 & 15,5 & 82,9 \\
40 ou mais & 7 & 1,4 & 100,0 & 404 & 17,1 & 100,0 \\
\hline Total & 485 & 100,0 & - & 2.361 & 100,0 & - \\
\hline
\end{tabular}

Fonte: Marcondes \& Garavazo, 2002, p. 13.

(a) Faixa de Tamanho de Plantel.

Conforme os dados da Tabela 3, entre 1822 e 1830, quase três quartos dos proprietários francanos possuíam plantéis de um a cinco cativos. Destes, 13,4\% possuíam plantéis unitários e 20,3\% possuíam plantéis de cinco escravos. O autor informa ainda que aproximadamente $4 / 5$ da escravaria estavam em plantéis de um a nove cativos, $90,4 \%$ dos plantéis encontrados. O restante, 20,4\% dos escravos, era possuído por apenas 6,6\% dos senhores. Aparentemente, essa estrutura se mostra menos concentrada do que a encontrada por Marcondes e Garavazo em Batatais, onde os proprietários de um a nove cativos somavam $88,9 \%$ e seus cativos representavam $48,8 \%$ da amostra considerada. 
Agora, considerando a localidade de São Simão. Em linhas gerais, na primeira metade do século XIX os habitantes da localidade viviam de suas lavouras de subsistência e da criação, de gado e outros pequenos animais. Dos 1.184 moradores arrolados pela lista nominativa de 1835, 891 (75,3\%) eram livres e 293 (24,7\%) cativos. A população livre era composta basicamente por brancos, 614 (68,9\%) e pardos, $260(29,2 \%)$, ao passo que mais de $4 / 5$ da população cativa era formada por negros. Esses moradores estavam divididos em 206 fogos, numa média de 4,3 livres e 1,4 cativos por fogo.

Tabela 3 - Estrutura da Posse de Escravos (Franca, 1822/1830)

\begin{tabular}{cc}
\hline Quantidade de escravos & $\begin{array}{c}\text { Proprietários 1822/1830 } \\
\text { (em porcentagem) }\end{array}$ \\
\hline 1 a 5 & 73,4 \\
6 a 10 & 20,0 \\
11 a 15 & 3,3 \\
16 a 20 & 3,3 \\
21 a 25 & - \\
\hline Total & 100,0 \\
\hline
\end{tabular}

Fonte: Oliveira, 1997, p. 83.

São Simão foi elevada à categoria de freguesia em 1842, e à categoria de vila em 1865. A antiga freguesia, no momento em que foi feita a lista nominativa, pertencia à localidade de Mogi-Mirim, e estava dividida em seis quarteirões: Ribeirão do Tamanduá, Ribeirão da Onça, Ribeirão da Prata I, Ribeirão Claro, Ribeirão da Divisa e Ribeirão da Prata II, nomes que fazem referência aos principais cursos de água da região.

No Mapa 2 pode-se observar que cada um desses quarteirões englobava diversas fazendas, sendo os mais extensos o da Onça e o do Tamanduá. As antigas vilas de São Simão, Ribeirão Preto e o atual distrito de Bonfim Paulista estavam localizados nesse último, enquanto a localidade de Sertãozinho no primeiro.

O quarteirão mais povoado era o Ribeirão da Prata II, que reunia os moradores das fazendas: da Prata, Águas Claras, São Lourenço, Posses e Boa Vista, entre outras. Ao todo eram 188 (72,6\%) livres e $71(27,4 \%)$ cativos distribuídos em 42 fogos, numa média de 4,5 livres e 1,7 cativos em cada fogo. 
O segundo quarteirão mais populoso era o da Prata I. Suas fazendas, Serra Azul, Serrinha e Serra Grande, possuíam 241 habitantes, dos quais $216(89,6 \%)$ livres e $25(10,4 \%)$ cativos, a maior porcentagem de livres encontrada. Essa população estava dividida em 47 fogos, resultando numa média de 4,6 livres e 0,5 cativos por fogo.

Em seguida aparecem os quarteirões mais extensos, o da Onça e o do Tamanduá. É interessante destacar que mesmo englobando a então freguesia de São Simão, o quarteirão do Tamanduá não era o terceiro mais populoso, ficando nesse posto o quarteirão da Onça. Possuindo em seu território a grande fazenda do Lageado, o quarteirão do Ribeirão da Onça abrigava 219 habitantes distribuídos em 34 fogos. Ao todo eram 138 (63,0\%) de livres e 81 (37,0\%) de cativos - a menor porcentagem de livres e a maior porcentagem de cativos encontrada - numa média de 4,1 livres e 2,4 cativos por fogo.

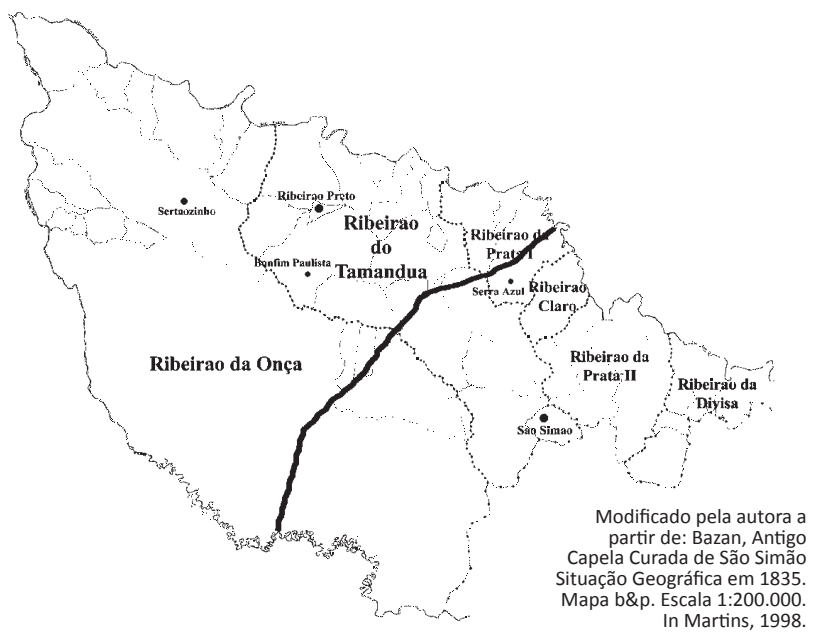

Mapa 2 - Quarteirões da Antiga Vila de São Simão (São Simão, 1835)

O quarteirão do Tamanduá, quarto mais populoso, possuía quase o mesmo número de habitantes que o da Onça, 214, dos quais 146 $(68,25 \%)$ livres e $68(31,8 \%)$ cativos. Esses indivíduos estavam divididos em 33 fogos, com média de 4,4 livres e 2,1 cativos por fogo. Os demais quarteirões - da Divisa e do Ribeirão Claro - possuíam, respectivamente, populações de 163 e 88 indivíduos. No quarteirão da Divisa os moradores estavam distribuídos em 33 fogos, numa média de 3,9 livres e 1,1 cativos por fogo. No quarteirão do Ribeirão Claro havia 4,4 livres e 0,8 cativos por fogo. 
Agora, considerando novamente todo o conjunto da população simonense, os chefes de fogos eram majoritariamente homens, com idades variando entre 18 e 83 anos. Entre estes foram encontrados 127 brancos, quatro pretos, dois crioulos e 54 pardos. Apenas 13 $(7,0 \%)$ eram solteiros e $4(2,0 \%)$ viúvos, sendo a maioria $(91,0 \%)$ casada. Sobre a naturalidade, a lista informa que existiam, além de brasileiros, um estrangeiro e um estrangeiro naturalizado. Nem todos eram alfabetizados, somente 59 (31,6\%) sabiam ler e escrever. As mulheres chefes de fogo somavam 19, com idades variando de 24 a 75 anos. Entre estas foram localizadas dez brancas $(52,6 \%)$ e nove $(47,4 \%)$ pardas. Com relação ao estado conjugal, eram seis $(31,6 \%)$ solteiras, duas $(10,5 \%)$ casadas e $11(57,9 \%)$ viúvas. Todas nascidas no Brasil e nenhuma era alfabetizada.

Tabela 4 - Ocupação dos Chefes de Fogo consoante Gênero (São Simão, 1835)

\begin{tabular}{lcccccc}
\hline \multirow{2}{*}{ Ocupações } & \multicolumn{2}{c}{ Homens } & \multicolumn{2}{c}{ Mulheres } & \multicolumn{2}{c}{ Total } \\
\cline { 2 - 6 } & Número & $\%$ & Número & $\%$ & Número & $\%$ \\
\hline Administrador ${ }^{(b)}$ & 2 & 1,1 & - & - & 2 & 1,0 \\
Agregado & 6 & 3,2 & 1 & 5,3 & 7 & 3,4 \\
Caçador (a) & 1 & 0,5 & - & - & 1 & 0,5 \\
Camarada de Jornal & 2 & 1,1 & - & - & 2 & 1,0 \\
Carpinteiro & 2 & 1,1 & - & - & 2 & 1,0 \\
Fazendeiro & 2 & 1,1 & - & - & 2 & 1,0 \\
Ferreiro & 2 & 1,1 & - & - & 2 & 1,0 \\
Jornaleiro & 4 & 2,1 & 2 & 10,5 & 6 & 2,9 \\
Lavrador ${ }^{(c)}$ & 139 & 74,3 & 9 & 47,4 & 148 & 71,8 \\
Lavrador e Criador & 1 & 0,5 & - & - & 1 & 0,5 \\
Lavrador e Inspetor de Quarteirão ${ }^{(d)}$ & 2 & 1,1 & - & - & 2 & 1,0 \\
Lavrador e Negociante & 1 & 0,5 & - & - & 1 & 0,5 \\
Negociante & 1 & 0,5 & - & - & 1 & 0,5 \\
Negociante de Carro de Bois ${ }^{(e)}$ & 2 & 1,1 & - & - & 2 & 1,0 \\
Sapateiro & 1 & 0,5 & - & - & 1 & 0,5 \\
Não informada & 19 & 10,2 & 7 & 36,8 & 26 & 12,6 \\
\hline Total & 187 & 100,0 & 19 & 100,0 & 206 & 100,0 \\
\hline
\end{tabular}

Fonte: Lista Nominativa de São Simão, 1835.

(a) $\mathrm{O}$ recenseador informou que este caçador era também agregado.

(b) Um dos administradores estava também apto para ser empregado.

(c) Conforme as observações da lista, entre os lavradores, vinte e um estavam na condição apto para ser empregado; três eram agregados; um era agregado e colhia também milho e feijão; um outro estava apto para empregos e colhia milho, feijão e arroz para seu sustento; um outro colhia milho e não informou a quantidade; e dois estavam aptos para empregos públicos.

(d) As observações da lista informavam que um destes estava apto para ser empregado.

(e) As observações da lista informavam que um destes estava apto para ser empregado. 
Como mostra a Tabela 4, dos 206 chefes de fogo apenas 180 declararam exercer algum tipo de ocupação. ${ }^{4}$ Entre os homens, as omissões representaram $10,2 \%$ e entre as mulheres $36,8 \%$. As ocupações mais comuns eram aquelas ligadas ao campo, sendo os lavradores maioria: $139(74,3 \%)$ dos homens e $9(47,4 \%)$ das mulheres. Cabe destacar a presença de dois carpinteiros, dois ferreiros, um sapateiro, um negociante e dois negociantes de carro de bois.

Os proprietários de escravos não eram muitos. Dos 206 fogos apenas $52(25,2 \%)$ possuíam escravos. Esses senhores eram em sua maioria do sexo masculino $(92,3 \%)$, brancos $(82,7 \%)$ e casados $(84,6 \%)$. Apenas quatro mulheres aparecem na relação - todas viúvas - sendo três brancas e uma parda.

Conforme a Tabela 5, quase a totalidade desses senhores proprietários de escravos dedicava-se à lavoura, atividade que ocupava também a maior parte dos cativos. Foram encontrados também, além de lavradores, administradores (2), fazendeiros (1), ferreiros (1), lavradores e criadores (1) e negociantes (1).

Tabela 5 - Ocupação dos Chefes de Fogo Proprietários de Cativos (São Simão, 1835)

\begin{tabular}{lcccc}
\hline Ocupação / Atividade & \multicolumn{2}{c}{ Proprietários } & \multicolumn{3}{c}{ Cativos } \\
\cline { 2 - 5 } & Número & $\%$ & Número & $\%$ \\
\hline Administrador & 2 & 3,8 & 24 & 8,2 \\
Fazendeiro & 1 & 1,9 & 2 & 0,7 \\
Ferreiro & 1 & 1,9 & 5 & 1,7 \\
Lavrador & 44 & 84,6 & 237 & 80,9 \\
Lavrador e Criador de Porcos & 1 & 1,9 & 8 & 2,7 \\
Lavrador e Inspetor de Quarteirão & 1 & 1,9 & 3 & 1,0 \\
Negociante de Carro de Bois & 1 & 1,9 & 11 & 3,8 \\
Não identificada & 1 & 1,9 & 3 & 1,0 \\
\hline Total & 52 & 100,0 & 293 & 100,0 \\
\hline
\end{tabular}

Fonte: Lista Nominativa de São Simão, 1835

De acordo com os dados da Tabela 6, a estrutura da posse mostra que a maior parte dos proprietários possuía plantéis que podem ser considerados pequenos e médios, sendo raras as grandes escravarias. Os detentores de plantéis unitários, apesar de representarem 19,2\%

4 Optou-se por conservar as ocupações informadas pela lista, ainda que a classificação de algumas dessas atividades como ocupação seja controversa. 
dos proprietários, possuíam apenas 3,4\% da escravaria, ao passo que o maior proprietário, 1,9\% dos senhores, detinha 7,2\% dos escravos.

Os plantéis mais comuns eram os de dois a nove cativos, somando estes, eram $33(63,5 \%)$, que concentravam mais da metade do conjunto de cativos, 164 elementos. Apenas oito proprietários $(15,4)$ possuíam plantéis de 10 a 19 elementos, num total de 98 (33,4\%) cativos. Pode-se considerar essa distribuição moderadamente desigual, sendo o índice de Gini calculado em 0,416.

Tabela 6 - Estrutura da Posse de Escravos e Razão de Sexo (São Simão, 1835)

\begin{tabular}{lccccccc}
\hline FTP(a) & \multicolumn{3}{c}{ Senhores } & \multicolumn{3}{c}{ Escravos } \\
\cline { 2 - 7 } & Número & $\%$ & $\%$ Acumulada & Número & $\%$ & \% Acumulada & Razão de sexo \\
\hline 1 & 10 & 19,2 & 19,2 & 10 & 3,4 & 3,4 & 100 \\
$2-4$ & 16 & 30,8 & 50,0 & 49 & 16,7 & 20,1 & 145 \\
$5-9$ & 17 & 32,7 & 82,7 & 115 & 39,2 & 59,4 & 161 \\
$10-19$ & 8 & 15,4 & 98,1 & 98 & 33,4 & 92,8 & 149 \\
20 ou + & 1 & 1,9 & 100,0 & 21 & 7,2 & 100,0 & 320 \\
\hline Total & $\mathbf{5 2}$ & $\mathbf{1 0 0 , 0}$ & - & $\mathbf{2 9 3}$ & 100,0 & - & 157 \\
\hline
\end{tabular}

Fonte: Lista Nominativa de São Simão, 1835.

(a) Faixa de Tamanho de Plantel

O maior proprietário de escravos era Gabriel de Souza Diniz Junqueira, solteiro, 18 anos e administrador de fazenda no quarteirão do Ribeirão da Onça. Sua família era proprietária da fazenda do Lageado, a maior da antiga vila de São Simão, e devia ser em alguma parte dessa fazenda que Gabriel desempenhava as funções de administrador. O restante da família chegaria à região mais tarde, sendo seu pai, Luiz Antonio de Souza Junqueira, inventariado em Casa Branca a partir de 1856. Da relação de bens desse inventário, constavam, entre outros, a grande fazenda do Lageado, um numeroso plantel de escravos, com 63 elementos, e um grande rebanho, composto por mais de 2.000 cabeças de gado. ${ }^{5}$

Com uma predominância tão grande das atividades ligadas à lavoura ou à criação, a análise da posse de escravos consoante ocupação dos proprietários, Tabela 7, mostra que a atividade lavoura era desempenhada por senhores de quase todas as faixas de tamanho de plantel.

5 Ao todo, eram 235 bois; 314 garrotes; 330 novilhas; 1.085 vacas, das quais 341 com crias; 52 muares, além de 9 animais não identificados. 
Um caso merece destaque, o de Vicente José das Cruzes, ferreiro, 50 anos e morador do quarteirão do Ribeirão do Tamanduá. Vicente é o único proprietário de cativos cuja atividade difere um pouco das encontradas anteriormente, não ficando limitada ao cultivo de gêneros ou à criação de animais.

Tabela 7 - Estrutura da Posse de Cativos consoante Ocupação do Proprietário (São Simão, 1835)

\begin{tabular}{lcccccc}
\hline & \multicolumn{7}{c}{ FTP(a) $^{(\text {a) }}$} \\
\cline { 2 - 7 } & 1 & $2-4$ & $5-9$ & $10-19$ & 20 ou + & Total \\
\hline Administrador & - & 1 & - & - & 1 & 2 \\
Fazendeiro & - & 1 & - & - & - & 1 \\
Ferreiro & - & - & 1 & - & - & 1 \\
Lavrador & 10 & 12 & 15 & 7 & - & 44 \\
Lavrador e Criador de Porcos & - & - & 1 & - & - & 1 \\
Lavrador e Inspetor de Quarteirão & - & 1 & - & - & - & 1 \\
Negociante de Carro de Bois & - & - & - & 1 & - & 1 \\
Não Especificada & - & 1 & - & - & - & 1 \\
\hline Total & 10 & 16 & 17 & $\mathbf{8}$ & 1 & $\mathbf{5 2}$ \\
\hline
\end{tabular}

Fonte: Lista Nominativa de São Simão, 1835.

(a) Faixa de Tamanho de Plantel

Os cativos encontrados nessa população totalizaram 293, dos quais $179(61,1 \%)$ homens e $114(38,9 \%)$ mulheres, com razão de sexo igualando 157. Essas pessoas eram solteiras $(74,1 \%)$ ou casadas $(25,9 \%)$ e não existiam viúvos. Com relação à cor, a lista informa a existência de pretos, pardos e crioulos, nas seguintes proporções: $84,6 \%$ pretos, $11,3 \%$ pardos e $4,1 \%$ crioulos.

Distribuindo os cativos em dois grupos - africanos e nacionais observa-se que entre os africanos a proporção de homens era maior. Entre os 111 africanos encontrados, contamos $84(75,7 \%)$ homens e apenas 27 (24,3\%) mulheres, com razão de gênero alcançando 31l. Já na população nacional, a relação entre os gêneros mostrava-se mais equilibrada, havendo uma ligeira predominância do elemento masculino. Dos 182 cativos nacionais, 95 (52,2\%) eram homens, enquanto 87 (47,8\%) eram mulheres, sendo a razão de gênero calculada em 109.

Ao analisar a questão das idades, percebe-se que a maior parte desses escravos era jovem e estava em idade produtiva, considerada aqui 
como sendo dos 15 aos 49 anos de idade. Observando os dados da Tabela 8 , nota-se que as crianças de zero a 14 anos representavam $33,1 \%$, os adultos $64,2 \%$ e aqueles com cinquenta anos ou mais tãosomente $2,7 \%$.

Tabela 8 - Idade da População Cativa segundo Gênero (São Simão, 1835)

\begin{tabular}{lcccccc}
\hline \multirow{2}{*}{ Faixas Etárias } & \multicolumn{2}{c}{ Homens } & \multicolumn{2}{c}{ Mulheres } & \multicolumn{2}{c}{ Total } \\
\cline { 2 - 7 } & Número & $\%$ & Número & $\%$ & Número & $\%$ \\
\hline $1-9$ & 35 & 19,6 & 27 & 23,7 & 62 & 21,2 \\
$10-14$ & 19 & 10,6 & 16 & 14,0 & 35 & 11,9 \\
$15-19$ & 25 & 14,0 & 18 & 15,8 & 43 & 14,7 \\
$20-29$ & 53 & 29,6 & 33 & 28,9 & 86 & 29,4 \\
$30-39$ & 36 & 20,1 & 11 & 9,6 & 47 & 16,0 \\
$40-49$ & 6 & 3,4 & 6 & 5,3 & 12 & 4,1 \\
$50-59$ & 2 & 1,1 & 3 & 2,6 & 5 & 1,7 \\
$60-69$ & 2 & 1,1 & 0 & 0,0 & 2 & 0,7 \\
$70-79$ & 1 & 0,6 & 0 & 0,0 & 1 & 0,3 \\
\hline Total & 179 & 100,0 & 114 & 100,0 & 293 & 100,0 \\
\hline
\end{tabular}

Fonte: Lista Nominativa de São Simão, 1835.

Ainda que o objetivo da presente análise não seja o de investigar a existência ou não de reprodução natural na massa cativa ora considerada, acredita-se ser relevante ressaltar que foi encontrada uma alta porcentagem de mulheres em idade fértil e um expressivo número de crianças, tanto de zero a nove quanto de zero a 14 anos. Mais de $50 \%$ das mulheres estava em idade fértil. As crianças de zero a nove anos totalizavam $62(21,2 \%)$ e as de zero a 14 anos somavam 97 $(33,1 \%)$. O cálculo da razão criança-mulher mostra que na população escrava de São Simão em 1835, havia 911 crianças de zero a nove anos para cada grupo de mil mulheres em idade fértil. Considerando as crianças de zero a quatorze anos esse índice sobe para 1.426 .

Analisando as idades segundo a origem do cativo, observa-se que entre os escravos de origem africana a porcentagem de elementos em idade produtiva e do sexo masculino era bem mais elevada do que entre os nacionais. Considerando o Gráfico 1, percebe-se que nas primeiras faixas etárias há predominância de nacionais, o que seria natural, pois todos os escravos filhos de africanos nascidos no Brasil tinham sua origem apontada como nacional. Já na terceira e quarta faixas o número de africanos é maior. Dos 86 cativos na faixa dos 20 
aos 29 anos, $48(55,8 \%)$ eram africanos e dos 47 na faixa dos 30 aos 39 anos, $30(63,8 \%)$, possuíam a mesma naturalidade.

Gráfico 1 - Idade dos Cativos consoante Origem (São Simão, 1835)

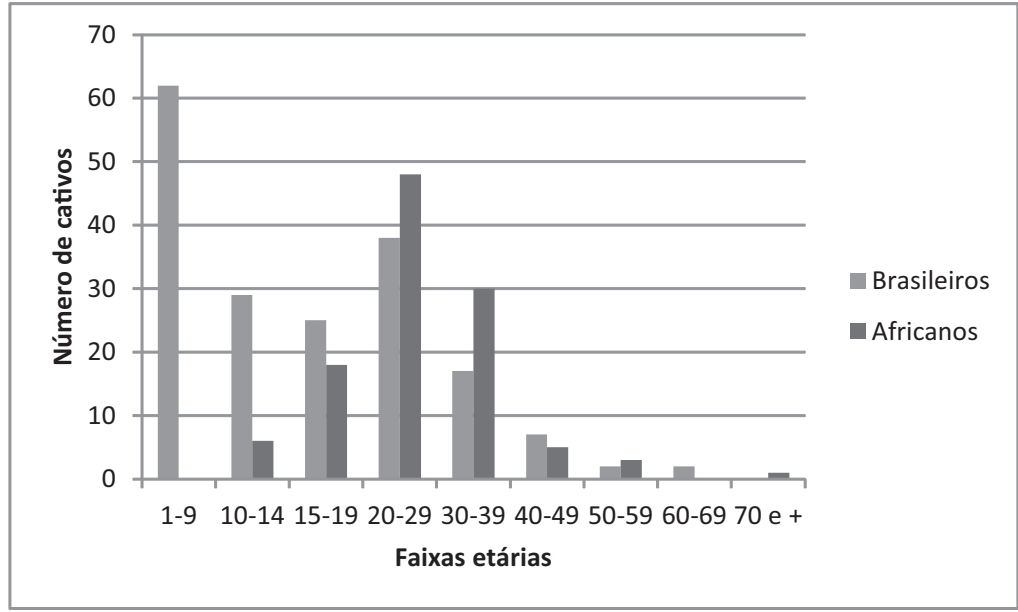

Fonte: Lista Nominativa de São Simão, 1835.

Infelizmente, a lista não informou nada a respeito da ocupação desses escravos e nem sobre as relações de parentesco dentro de um mesmo plantel, limitando-se a apresentar os dados já analisados anteriormente.

Com as informações da lista nominativa de 1835 foi possível verificar que a população da antiga freguesia de São Simão estava dispersa dentro de um vasto território, vivendo da criação de gado e da agricultura de subsistência. A posse cativa apresentava-se moderadamente desigual e a maior parte dos plantéis existentes possuía de um a nove cativos. É possível supor certo nível de mercantilização, assim como capacidade de geração de riqueza. Caso contrário, seria difícil justificar a manutenção do plantel de cativos e a própria atividade criatória. Como foi visto, parcela considerável dos cativos estava em idade produtiva e a presença de africanos na faixa dos 20-39 anos era significativa. Assim, percebe-se, tanto pela necessidade de comercialização dos animais, como pela necessidade de manutenção do plantel de cativos, uma ligação com centros econômicos e mercantis mais dinâmicos, possivelmente as localidades de Casa Branca e Franca. Em Minas Gerais, como apontado por Saint-Hilaire, a ligação seria com a vila de São João Del Rei. 


\section{A Introdução da Cafeicultura na Região}

Segundo Pierre Monbeig, a chegada do café no Nordeste Paulista não foi resultado de um movimento brusco, mas sim a consequência natural de um processo que caracterizou toda a cafeicultura brasileira durante o século XIX. Atividade itinerante, o café abandonava as regiões tão logo a produtividade das árvores decaía. Esse movimento provocava constantes alterações nas quantidades produzidas, o que não era percebido quando se analisavam os dados em conjunto, pois uma nova região sempre substituía a anterior. Sérgio Milliet, dividindo a província paulista em regiões, conseguiu caracterizar muito bem tal dinâmica. Conforme o Mapa 3, Milliet considerou sete regiões: Norte, Central, Paulista, Mogiana, Araraquarense, Noroeste e AltaSorocabana. ${ }^{6} \mathrm{~A}$ análise da produção de café foi feita com base em diversos levantamentos, censos e estatísticas, abrangendo um período de aproximadamente um século.

Entre 1836 e 1854 a produção da província cresceu vertiginosamente, passando de 590.066 para 3.534.256 arrobas, praticamente sextuplicando a quantidade produzida em 1836. Mais significativos ainda foram os números de duas regiões: a Central e a Mogiana. A quantidade produzida pela primeira passou de 70.378 para 491.397 arrobas e os números da segunda passaram de 821 para 81.750 arrobas. Esses números dão ideia da expansão da cultura no Nordeste Paulista.

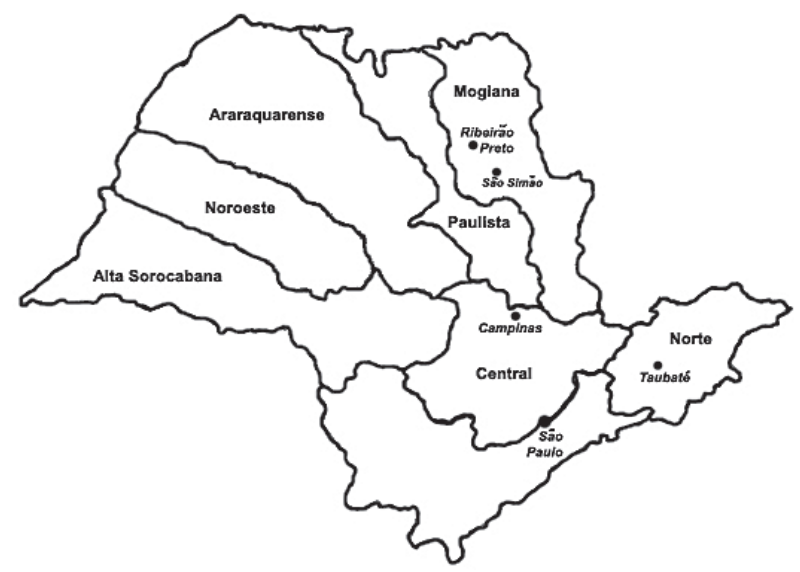

Mapa 3 - Divisão do Território Paulista Proposta por Milliet (São Paulo, 1938) Fonte: Modificado a partir de: Milliet, 1938, p. 24.

6 Para maiores informações sobre as regiões definidas por Milliet, ver Sérgio Milliet, 1938. Em especial páginas 10-12. 
Uma das dificuldades da expansão cafeeira para áreas planaltinas era o transporte. A distância entre as cidades produtoras e os centros de escoamento deveria ser vencida com a utilização de tropas de mulas e carros de bois. Todavia, o estado de conservação das estradas era precário. Até mesmo as vias consideradas vitais, como a estrada que ligava Santos a São Paulo, estavam comprometidas.

Durante o período 1834-1850, nos relatórios dos presidentes da Província de São Paulo, é constante a referência ao problema das estradas. Eram numerosos os pedidos para que se abrissem novas vias de comunicação, mas a falta de recursos financeiros, o mau planejamento e a falta de mão de obra especializada dificultavam a concretização das obras. (Silva, 2008, p. 18)

Muitos dos caminhos existentes haviam sido abertos de maneira aleatória, muitas vezes para satisfazer o interesse privado e não o público, sem a orientação e a supervisão de engenheiros ou pessoas capacitadas. A falta de planejamento e técnica gerava estradas e pontes que logo se deterioravam, muitas vezes tornando-se intransitáveis. A falta de um órgão administrativo, responsável pelo direcionamento dos esforços e dos recursos, contribuía para a manutenção desse ineficiente sistema.

A ausência de especificação das responsabilidades respectivas contribuía para o mau andamento dos serviços públicos, estimulava a negligência das autoridades locais e dos interesses particulares. Discutia-se a quem pertencia a obrigação de conservar determinada estrada, se aos fazendeiros ou às Câmaras, se a estas ou ao governo provincial; enquanto isso, os caminhos permaneciam em péssimo estado. (Costa, 1998, p. 215)

A cafeicultura paulista suportou esse sistema de transporte rudimentar até a segunda metade do século XIX. Em 1856, uma concessão feita ao Barão de Mauá, ao Marquês de Monte Alegre e a J. A. Pimenta Bueno previa a construção de uma estrada de ferro ligando Santos às vilas de São Paulo e Jundiaí. A obra foi concluída em 1867, sendo a administração da estrada passada ao capital inglês, dando origem à São Paulo Railway Company. A partir de Campinas, outra empresa seria responsável pela construção e prolongamento dos trilhos: a Companhia Paulista de Estradas de Ferro, a primeira companhia ferroviária fundada com capital nacional. (Saes, 1981) 
A partir do momento em que a São Paulo Railway inaugurou o trecho entre Santos e Jundiaí, o ritmo de construção de novas linhas e ramais foi acelerado. Partindo de Jundiaí, a Companhia Paulista logo chega aos demais núcleos cafeicultores: em 1872 foi inaugurado o trecho entre Jundiaí e Campinas; em 1876 o trecho até Rio Claro e o ramal até Descalvado; entre 1873 e 1882, inauguraram-se os trechos ligando Itu a Jundiaí, São Paulo a Ipanema, Tietê e Botucatu; em 1884 foi completado o trecho entre São Paulo e Atibaia e prolongaram-se os trilhos que ligavam Rio Claro a São Carlos, chegando-se a Araraquara; ainda em 1884, foram concluídos os ramais de Brotas, Dois Córregos e Jaú. (Costa, 1998, pp. 220-221)

Em 1872, na cidade de Campinas, ocorre a fundação da companhia que seria responsável por atender os municípios do chamado Oeste Novo. Essa era a Companhia Mogiana de Estradas de Ferro, que inicialmente planejava chegar apenas até a cidade de Mogi-Mirim. Os planos foram logo revistos e a companhia decidiu construir linhas até as localidades de Casa Branca e Franca. O contrato que permitiu à Mogiana chegar até Casa Branca previa também a construção de ramais até São Simão e Ribeirão Preto. A inauguração da estação de Ribeirão Preto aconteceu no dia 23 de novembro de 1883. A expansão da ferrovia permitiu então a expansão do café em direção do planalto paulista.

A produção de café não era uma atividade simples. Conforme os processos de beneficiamento iam se desenvolvendo, e no Brasil começava a transição entre o trabalho escravo e o assalariado, as fazendas tornavam-se cada vez mais complexas. Além das plantações, as fazendas cafeeiras contavam com várias outras instalações. Havia os tanques onde os frutos eram lavados após a colheita, os terreiros nos quais eram expostos ao sol para secar, máquinas para o descaroçamento e máquinas que separavam e classificavam os grãos. Além desses equipamentos havia residências para o fazendeiro e sua família, senzalas, colônias para imigrantes, cocheiras, estrebarias e oficinas diversas.

Para a formação de um cafezal era necessário fazer, em primeiro lugar, a limpeza do terreno. O tipo de solo preferido pelos paulistas era a terra roxa. Segundo Pierre Monbeig, a verdadeira terra roxa era rara. Além de possuir alto teor de matéria orgânica esse tipo de solo era também rico em calcário, apresentando um $\mathrm{pH}$ quase sempre superior a sete. Essas especificidades fazem reduzir a incidência desse 
tipo de solo a apenas $2 \%$ do território paulista. A preferência por esse tipo de terreno estava também associada à sua profundidade. $\mathrm{A}$ raiz de um cafeeiro adulto podia alcançar até cinco metros, por essa razão as terras realmente adequadas para cafeicultura eram as que conservavam sua fertilidade até o final das raízes. Em São Paulo, a terra roxa recobre parte dos planaltos de Ribeirão Preto, Araraquara, Jaú e São Manuel. Aqui nota-se um diferencial da região de Ribeirão Preto. Observando o mapa de Monbeig, reproduzido abaixo como Mapa 4, a incidência de terra roxa era significativamente maior nas áreas simonense e ribeirãopretana. (Monbeig, 1998, pp. 77-78) Não obstante, das localidades beneficiadas por essa grande mancha de terra roxa sobressai o bom desempenho conseguido por Ribeirão Preto.

Um grupo de oito ou dez cativos conseguia limpar um alqueire de terra por dia. Aos trabalhadores livres, pagava-se $2 \$ 000$ réis por dia e se fornecia a alimentação, ou de $25 \$ 000$ a $30 \$ 000$ réis sem alimentação. Com a terra limpa, começava-se a derrubada das árvores grandes; para esse serviço, o fazendeiro geralmente não empregava seus próprios cativos, dado que o trabalho de derrubada era muito arriscado. Por via de regra, eram utilizados os caboclos ou os mineiros, que, segundo informações de Laërne, faziam esse trabalho de maneira eficiente. Em São Paulo, pagava-se entre $60 \$ 000$ e $80 \$ 000$ réis pela derrubada de um alqueire de mata e de $30 \$ 000$ a $40 \$ 000$ pela derrubada de um alqueire de capoeira. Outra maneira de se fazer a preparação do terreno era a queimada. Essa geralmente era feita logo após o inverno, época em que a vegetação estava mais ressecada, durante os meses de setembro e outubro. (Läerne, 1885, pp. 243-244)

Após a preparação do terreno, as mudas eram plantadas em carreiras, transplantadas dos viveiros quando atingiam aproximadamente dois anos. Geralmente, os viveiros eram estabelecidos em terrenos abrigados do sol, no meio de capoeiras e até mesmo de cafezais já formados. Outra maneira consistia na plantação por meio de sementes, nesse caso a semeadura era feita nos meses de setembro, outubro e novembro. Eram colocadas várias sementes em uma única cova, transplantando-se as mudas excedentes que se formavam para outros locais, geralmente cafezais já prontos que apresentavam falhas. (Läerne, 1885, p. 252) 


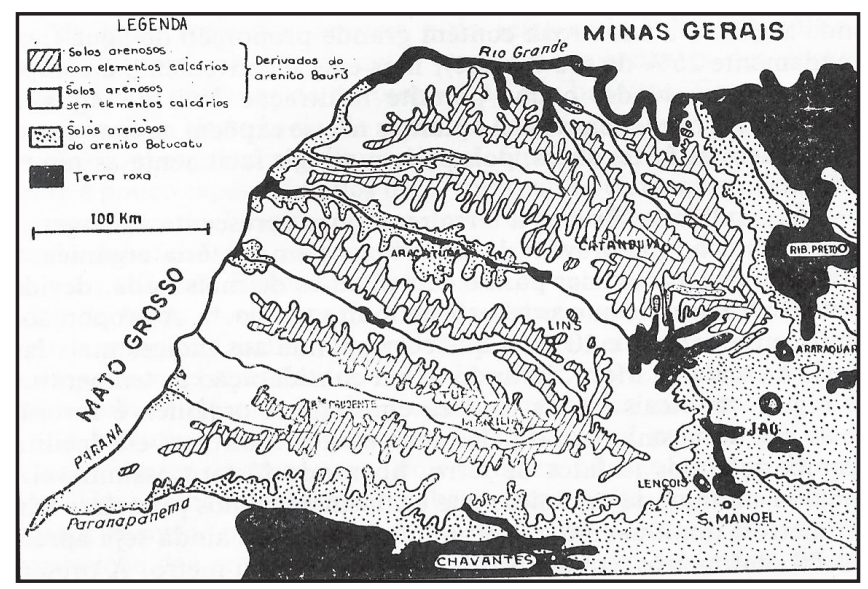

Mapa 4 - Solos da Zona Pioneira Paulista

Fonte: Monbeig, 1998, p. 77.

O número de pés de café plantados em cada alqueire de terreno variava muito, dependendo da distância entre mudas que cada fazendeiro adotava. Conforme os apontamentos de Laërne, o número de plantas por alqueire de terra podia alcançar quase quatro mil mudas, se plantadas de doze em doze palmos. (Läerne, 1885, p. 241) Nas propriedades paulistas, plantavam-se mudas com no mínimo quatorze palmos de distância, reduzindo o número de pés por alqueire para 2.869. (Läerne, 1885, p. 253) Durante os primeiros quatro anos de um novo cafezal, podiam-se plantar gêneros de subsistência entre as jovens árvores: o milho era semeado durante os meses de setembro, outubro e novembro; o feijão e a mandioca, em fevereiro ou março. Além desses, plantava-se também a batata e o arroz.

Em algumas localidades, a cana-de-açúcar era plantada da mesma maneira, mas a ocorrência desta não era comum. (Läerne, 1885, pp. 256-257) Após três ou quatro anos começavam as primeiras safras. No Brasil, o cafeeiro florescia de duas a três vezes por ano, por isso, a colheita era feita em maio, um momento intermediário. Eram colhidos frutos já secos, maduros e verdes, todos de uma só vez. (Läerne, 1885, p. 264)

Sendo uma atividade menos dispendiosa do que a produção de açúcar, a cafeicultura também atraiu os pequenos e médios lavradores, sendo esses, normalmente, os responsáveis pela introdução do novo 
cultivo em uma determinada localidade. ${ }^{7}$ Esse período inicial era o mais difícil, pois os precursores começavam as plantações sem saber, ao certo, quais seriam as reações da planta.

Plantado de maneira apropriada e em terras de boa qualidade, o cafeeiro produzia satisfatoriamente por 20 ou 25 anos. A primeira safra ocorria quando o cafeeiro atingia os quatro anos. Normalmente, as duas colheitas iniciais não apresentavam bons resultados. Os melhores resultados eram alcançados entre a terceira e a décima safras.

A partir da décima primeira safra, o volume produzido começava a cair, tendência que se acentuava após a vigésima safra. Uma plantação em boas condições costumava render cerca de cem arrobas por mil pés de café. Um cafezal com trinta anos rendia, em média, de vinte a trinta arrobas por mil pés. Nas condições excepcionais do oeste paulista, cafezais já velhos chegavam a render até setenta arrobas por mil pés. (Canabrava, 1971, p. 93)

A necessidade de braços era grande, já que todos os processos, desde o plantio, passando pelas cinco carpas anuais até a colheita, exigiam o emprego intensivo de mão de obra. Quando disponível, utilizavase o braço escravo e, na falta deste, o livre assalariado. Geralmente, preferia-se o trabalho livre para a derrubada das matas e o cativo para o cuidado das plantações e colheita dos frutos. Essa grande demanda de mão de obra promoveu um acréscimo populacional muito acentuado nas localidades cafeeiras.

As informações da lista nominativa de 1835 mostram que, naquele ano, a atividade cafeeira não havia ainda chegado a São Simão. A historiografia considera que a introdução da cultura cafeeira em São Simão se deu durante a década de 1840 , por iniciativa de Joaquim Pereira de Macedo. (Oliveira, 1975, p. 324) Joaquim não aparece na lista nominativa de 1835 , sendo localizado apenas a partir de 1855 nas listas de qualificação de votantes. Neste mesmo ano de 1855 ele tinha 41 anos, era casado e vivia no Quarteirão da Matriz, onde exercia atividades de negociante. $\mathrm{Na}$ lista de 1860 ele aparece vivendo no mesmo quarteirão, mas exercendo atividade distinta, a de lavrador.

7 Ver sobre isso o artigo de Nelson H. Nozoe e José Flávio Motta, Os produtores eventuais de café: nota sobre os primórdios da cafeicultura paulista (Bananal, 1799-1829). (Nozoe \& Motta, 1999) 
As mesmas informações se repetem na lista de 1867. Ao que tudo indica, Joaquim desenvolvia a cultura cafeeira na Fazenda da Prata, na qual ele aparece listado como um dos condôminos no momento de sua divisão judicial, na década de 1870. (Martins, 1998, p. 233) Infelizmente, o inventário de Joaquim não foi localizado.

A região possuía todas as condições de solo, clima, já se encontrava desbravada, possuía ligação mercantil com outros centros comerciais, concentrava certo número de cativos, pessoas com capital e interessadas em diversificar suas atividades, além de trabalhadores nacionais livres e dispostos ao trabalho. A base, por assim dizer, estava preparada para receber o grande complexo cafeeiro, entendido aqui como sendo formado pela própria atividade cafeeira, as ferrovias, os bancos e todos os desdobramentos econômicos que a cafeicultura proporcionou.

No início da década de 1870, foi organizado e publicado por Antonio José Baptista de Luné e por Paulo Delfino da Fonseca o Almanak da Província de São Paulo para 1873. Nele constam uma breve descrição da localidade de São Simão e uma lista de seus principais habitantes, na qual foram indicadas as atividades correspondentes a cada um deles. Considerando-se apenas os fazendeiros de café, os criadores de gado vacum e/ou suíno, os fazendeiros de cana-deaçúcar e os lavradores, elaborou-se a Tabela 9. 


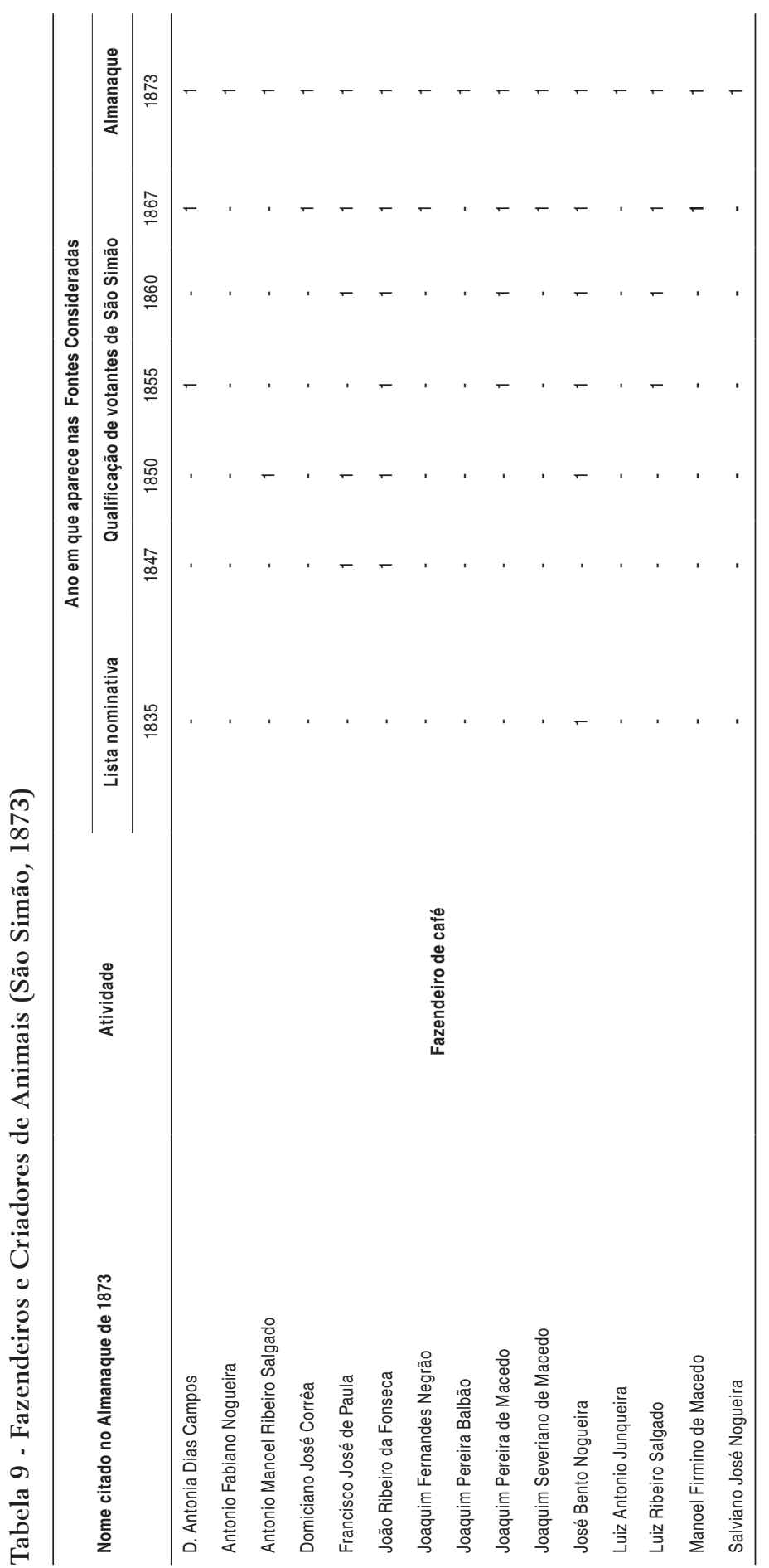

Est. Econ., São Paulo, vol. 42, n.2, p. 363-400, abr.-jun. 2012 


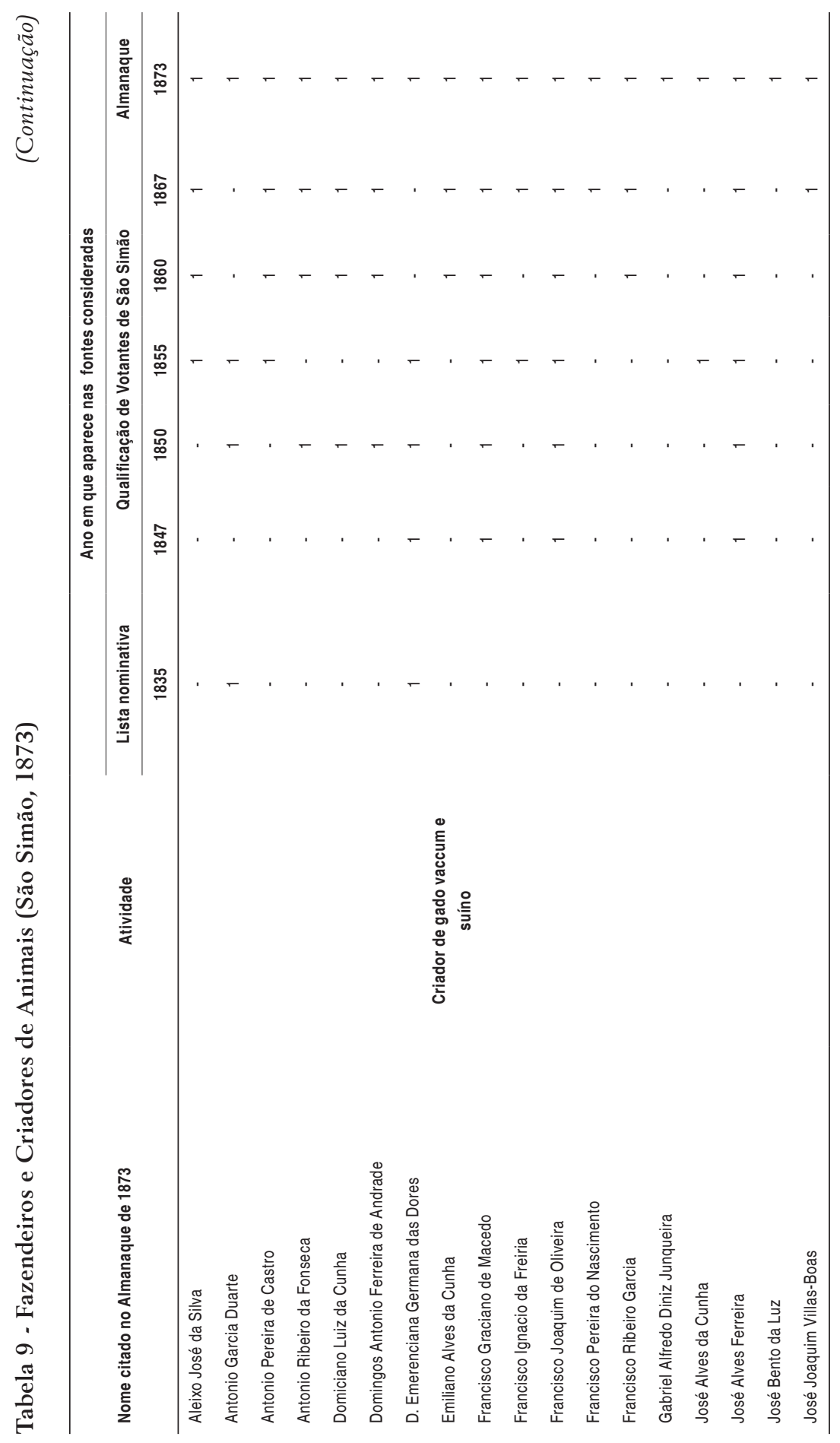




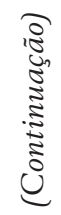

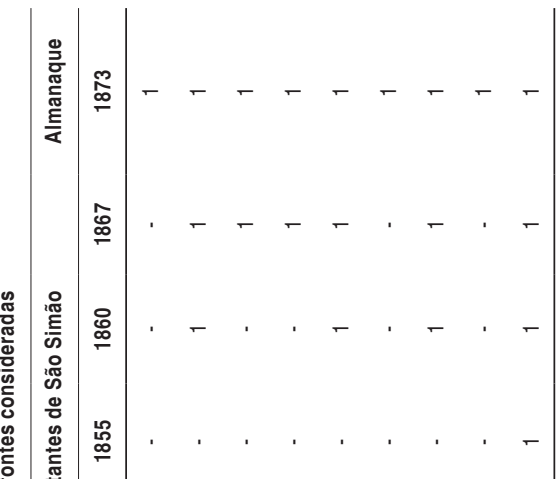

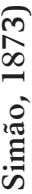

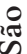

$\cdot$

흥

这

흠

¿

点

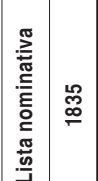

$\underset{\infty}{\infty}$

ֻ

ซี

而

v

อั

U

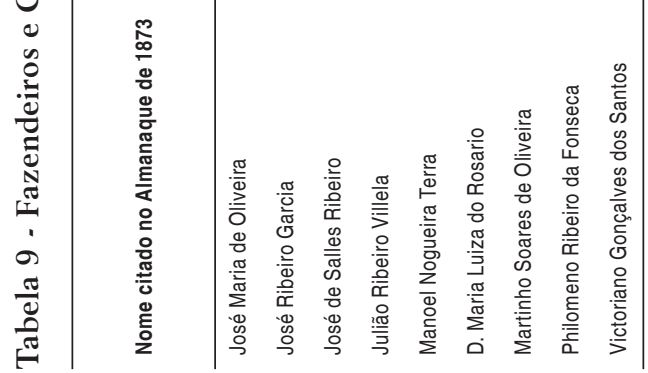




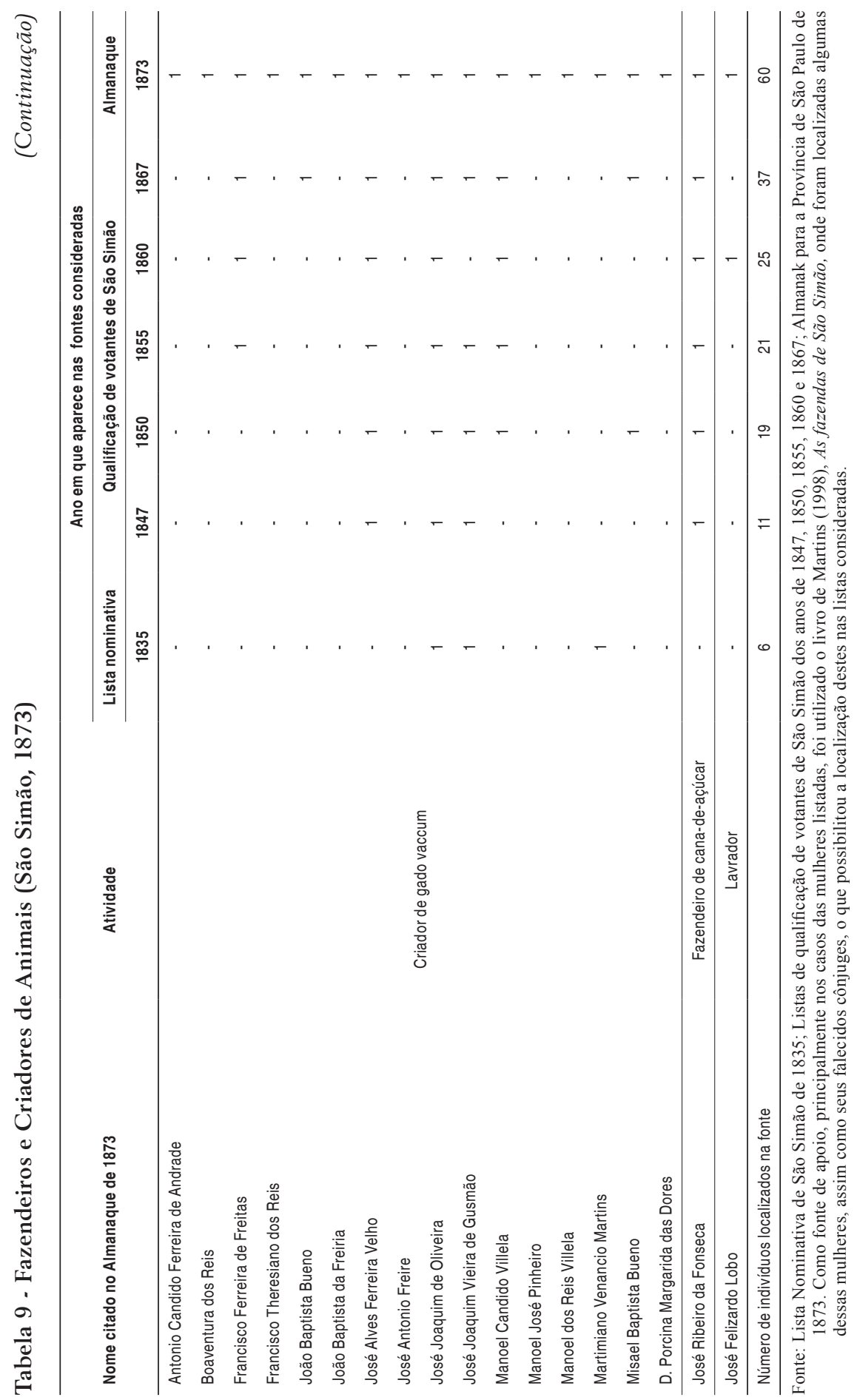


Nela é possível observar, partindo-se dos nomes arrolados em 1873, quando esses indivíduos começam a aparecer nas listas, quer seja lista nominativa quer sejam listas de qualificação de votantes da localidade. Para cada ano, quando da localização do indivíduo, foi colocado o número 1 na tabela. ${ }^{8}$ Caso o mesmo não tenha sido localizado, o valor informado foi nulo. À primeira vista nota-se que poucos dos listados aparecem arrolados na localidade desde 1835. Ao todo, apenas seis estavam na região desde 1835 e foram localizados na lista nominativa.

A maioria dos indivíduos parece ter chegado à localidade a partir da década de 1840. Esse resultado, de certa maneira, é esperado, considerando-se que a historiografia local aponta justamente essa década, a de 1840, como sendo a da introdução do cafeeiro na região. Acredita-se que a introdução da cafeicultura, atividade em maior expansão no período, tenha aquecido a ocupação das terras e a economia locais.

Contudo, é interessante destacar, observando-se a distribuição por atividade desses seis indivíduos localizados na lista nominativa de 1835, que apenas um era cafeicultor, sendo os demais criadores de gado vacum e/ou suíno. Joaquim Pereira de Macedo, considerado o introdutor da cafeicultura em São Simão ainda na década de 1840, somente aparece nas listas de qualificação de votantes a partir de 1855, o que pode significar que tenha introduzido o café e se mudado posteriormente para a vila, registrando-se como votante somente a partir daquele ano.

O cafeicultor mais antigo na relação é José Bento Nogueira, localizado na lista nominativa de 1835, vivendo com seus pais no fogo 32 do Quarteirão do Ribeirão do Tamanduá. Nessa época, José tinha ainda nove anos de idade. As atividades desenvolvidas por seus pais eram a lavoura e a criação de porcos e gado. Os gêneros produzidos eram aqueles ligados à subsistência da família e de seus 16 cativos, tais como o milho (trinta carros), o feijão (vinte alqueires) e o arroz (dez alqueires). Considerando-se os padrões da localidade, esse plantel de escravos era indicativo de certa riqueza, já que a metade

8 É sabido que a busca por indivíduos em listas de qualificação e na lista nominativa apenas considerando-se seus nomes não é livre de erros. Havia homônimos e muitas vezes os nomes não eram informados da mesma maneira em todas as listas. Para elaboração da Tabela 9, buscou-se localizar exatamente os mesmos nomes do Almanak nas listas, como forma de minimizar possíveis erros e confusões. 
dos proprietários de escravos listados possuía plantéis de um a nove elementos, e apenas um terço deles possuía escravarias de dez a 29 elementos, tal como a de José (pai).

José (filho) começa a aparecer nas listas de qualificação de votantes em 1850, vivendo no mesmo Quarteirão do Tamanduá, solteiro, tendo aproximadamente 26 anos. Nas demais listas, continua habitando o Quarteirão do Tamanduá, aparecendo como casado em 1855 e 1860, e viúvo em 1867. Nesse último registro ele tinha aproximadamente 39 anos. Faleceu poucos anos depois, sendo inventariado em São Simão a partir de 1879. Infelizmente, não se tem os dados do inventário de José (filho).

A partir da introdução em São Simão, o cultivo do café se espalha lentamente durante as duas décadas seguintes, chegando no final da década de 1860 à região que se tornaria Ribeirão Preto, localidade que no final do século XIX se tornaria mundialmente conhecida por sua produção cafeeira.

Dentre os mais de 500 inventários consultados no Arquivo do Fórum de Ribeirão Preto e no Fórum de São Simão, o primeiro a indicar o cultivo de café em terras ribeirãopretanas foi o de José Venâncio Martins, falecido em 1868.

A família de José Martins já vivia em terras da antiga freguesia de São Simão pelo menos desde 1822. Nesse ano, seu pai comprou de José Vitorino de Camargo uma parte de terras no lugar denominado Serra Azul. Em 1844, a mãe de José, após falecimento de seu marido, resolve fazer a divisão de seus bens ainda em vida, ficando as terras e os demais bens do extinto casal em posse de filhos e netos. (Martins, 1998, p. 347-348) Ao que tudo indica, José sempre viveu nas terras da fazenda Serra Azul. Segundo a lista nominativa de 1835, naquele ano ele tinha 32 anos, morava no mesmo quarteirão que sua mãe, era casado e tinha cinco filhos. Para ajudar nos trabalhos da lavoura e na criação de animais, José contava com a mão de obra de oito cativos, com idades variando entre dois e 30 anos. Sua renda anual era de aproximadamente $200 \$ 000$ réis, proveniente da lavoura e da criação de porcos. A produção anual de gêneros era de 20 carros de milho, 20 alqueires de feijão e outros 20 de arroz. Não havia ainda a presença do café. 
Voltando ao inventário, conforme as informações do processo, José faleceu no ano de 1868 em terras da antiga freguesia de São Sebastião do Ribeirão Preto, onde o inventário foi iniciado. De acordo com as informações da lista de qualificação de votantes de São Simão, José faleceu com aproximadamente 65 de idade. A segunda esposa de José, Maria Francisca, foi a inventariante.

A primeira esposa de José chamava-se Anna Leopoldina de Ávila. Desse primeiro consórcio ficaram os seguintes filhos: Maria Victoria, na época já falecida; Francisco Venâncio Martins, que faleceu depois do inventariado; Joaquim Venâncio Martins; Francisco de Paula Martins; Helena Leopoldina de Ávila, também já falecida; José Venâncio Martins; e Maria das Dores. Do segundo casamento de José ficaram mais seis filhos: Martimiano Venâncio Martins, 15 anos; Paulina; Silvana, 11 anos; Lucinda, cinco anos; Maria, três anos; e Luis, com apenas três meses de idade.

A análise das informações do inventário de José mostra que no momento de seu falecimento ele era um próspero criador de gado e produtor de gêneros alimentícios, entre eles o café. A relação de bens possuídos pela família corrobora essa firmação, pois deixa transparecer a boa condição financeira do casal. O patrimônio de José estava dividido basicamente entre imóveis e escravos, correspondendo esses a $94,3 \%$ do total do monte mor. Os demais grupos de bens - bens móveis, animais e dívidas passivas - perfaziam 5,7\% do total inventariado, o que não significa serem esses grupos pouco significativos. Os valores alcançados tanto pelos animais como pelos bens móveis são bem mais elevados do que o valor comumente encontrado nos demais processos da época.

Os bens móveis eram variados e continham até alguns itens que podem ser considerados de luxo, tais como a quarta parte de um faqueiro de prata. Além deste, foram encontrados também: um oratório com imagens, um armário, quatro rodas de fiar, um tear, diversas canastras e caixas, tachos e panelas de ferro ou cobre. A produção da lavoura e o sal, indispensável para o gado, aparecem também na relação de bens móveis. $\mathrm{Na}$ época do inventário, havia 50 alqueires de café com casca, 15 carros de milho e 23 sacos de sal. A criação de gado era composta por 29 cabeças de bovinos, entre estas nove vacas com cria, dez bois e nove novilhos. Além destes animais, José possuía também seis equinos e 30 porcos prontos para o abate. 
Com relação aos escravos, a família possuía um plantel de 21 cativos, dos quais 12 homens e nove mulheres. A idade média dos homens foi calculada em 25 anos e a das mulheres em 21, excluindo-se dos cálculos uma cativa para a qual não havia informação de idade. $\mathrm{O}$ preço dos cativos variava muito. Entre os homens, iam de $400 \$ 000$ a 1:500\$000 réis e entre as mulheres, os preços iam de $100 \$ 000$ e 1:300 $\$ 000$. O plantel inventariado, se comparado àquele de 1835 , mostra-se ampliado, passando de oito para 21 cativos. Um crescimento substancial que não pode ser explicado apenas pela reprodução natural de seu antigo plantel.

Com relação aos bens imóveis, José possuía diversas partes de terras, além de lavouras de milho e café. As terras mais valiosas eram as da fazenda Serra Azul, avaliada em 8:000\$000 réis. As demais partes de terra do casal estavam localizadas na fazenda da Figueira e na fazenda Bocaiúva. Foram avaliadas também quatro casas de morada, três na fazenda da Figueira e uma na fazenda da Serra Azul. Os nove alqueires de lavoura de milho foram avaliados em $180 \$ 000$ e o cafezal em 1:150\$000 réis.

As dívidas ativas - os valores a receber de terceiros - eram reduzidas, sendo compostas por apenas dois valores a receber de herdeiros do próprio espólio: os filhos Joaquim Venâncio Martins e Francisco Venâncio Martins, já falecido. Essas duas dívidas totalizavam $487 \$ 000$ réis. Não havia dívidas passivas. O monte mor alcançou o valor de 49:211\$000, que após descontadas as custas gerou um monte partível de 48:811\$100. A viúva recebeu a meação, no valor de 24:405\$550 réis, e cada um dos filhos recebeu 1:877\$350.

Calculado em libras esterlinas, o monte mor de José Martins alcançou aproximadamente $£ 3.421$. Os inventários de alguns de seus descendentes também puderam ser localizados. Nota-se, analisando os patrimônios familiares arrolados, uma nítida relação entre enriquecimento e atividade cafeeira. Na década de 1890 faleceram duas de suas netas, Francisca e Delfina. Ambas eram casadas e foram inventariadas em Ribeirão Preto, tendo seus montes mores alcançado as cifras de $£ 5.758$ e $£ 7.237$. Entre as atividades encontradas nos inventários uma prevalece: o café. ${ }^{9}$

9 Como deflator foi utilizada a taxa de câmbio implícita publicada pelo IBGE no livro Estatísticas históricas do Brasil. Séries Econômicas, Demográficas e Sociais de 1550 a 1988. (IBGE, 1990, pp. 568-571) 


\section{Considerações Finais}

O objetivo do presente artigo era analisar a estrutura produtiva anterior à chegada do café na região da antiga vila de São Simão, em meados do século XIX. Foram utilizadas como fontes de dados a lista nominativa de 1835 , as listas de qualificação de votantes do período 1847-1873, e como fonte complementar o conjunto de inventários post-mortem localizados nos Primeiro e Segundo Ofícios de São Simão e Ribeirão Preto.

A ocupação da região nordeste da antiga província paulista foi intensificada com a decadência da mineração em Minas Gerais e a chegada dos chamados entrantes mineiros. Em 1835, a lista nominativa mostrou uma economia baseada na criação de gado e outros animais, além da produção de gêneros de subsistência. A estrutura da posse de escravos revelou a predominância das pequenas posses, sendo raras as grandes escravarias. Na composição da massa cativa notase a presença majoritária de cativos em idade produtiva, sendo que entre estes, na faixa dos 20 aos 39 anos, era significativa a presença de africanos.

Essa estrutura produtiva, garantindo a ocupação primitiva do solo e permitindo a manutenção de um contingente populacional tanto livre como cativo, possibilitou que a partir da década de 1840 a localidade passasse por um processo de aquecimento econômico, marcado pelo estabelecimento de diversos criadores de gado bovino/ suíno e cafeicultores. O café, introduzido durante a década de 1840, desenvolveu-se rapidamente, absorvendo parte da estrutura produtiva pré-existente, descrita na lista nominativa de 1835.

\section{Fontes Primárias Impressas e Manuscritas}

Lista Nominativa da Freguesia de São Simão, 1835. Arquivo do Estado de São Paulo. Microfilmado.

Listas de Qualificação de Votantes de São Simão: de 1847 a 1867. Arquivo do Estado de São Paulo, lata 5933.

Inventários post-mortem dos Primeiro e Segundo Ofícios de São Simão e Ribeirão Preto.

D’Alincourt, Luiz. Memória sobre a Viagem do Porto de Santos à Cidade de Cuiabá. São Paulo: Martins, 1953.

Läerne, C. F. Bresil et Java : rapport sur la culture du cafe en Amerique, Asie et Afrique. Haye: Martinus Nijhoff, 1885.

Luné, A. J. B. \& Fonseca, P. D. da. Almanak da Província de São Paulo para 1873. Primeiro Anno. São Paulo: Typographia Americana, 1873. 
Müller, D. P. Ensaio d'um Quadro Estatístico da Província de São Paulo: ordenado pelas leis municipais de 11 de julho de 1836 e 10 de março de 1837. (3ª facsimilada ed.). São Paulo: Governo do Estado, 1978.

Saint-Hilaire, A. d. Viagem à Província de São Paulo. São Paulo: Martins, 1976.

\section{Referências}

Brioschi, L. R. (1995). Criando História: paulistas e mineiros no nordeste de São Paulo, 1725-1835. Faculdade de Filosofia, Letras e Ciências Humanas da Universidade de São Paulo, Departamento de História Social. São Paulo: (mimeo).

Brioschi, L. R. (1999). Caminhos do Ouro. In: C. d. Bacellar, \& L. R. Brioschi, Na Estrada do Anhangüera. São Paulo: Humanitas FFLCH/USP.

Canabrava, A. P. (1971). A Grande Lavoura. In: S. B. Holanda, História Geral da Civilização Brasileira. São Paulo: Difusão Européia do Livro.

Costa, E. V. (1998). Da senzala à colônia. São Paulo: UNESP.

Garavazo, J. (2002). Economia e demografia escrava no nordeste paulista: uma área de abastecimento interno. Faculdade de Economia, Administração e Contabilidade de Ribeirão Preto - USP, Departamento de Economia. Ribeirão Preto: (mimeo).

Gorender, J. (1992). O escravismo colonial. São Paulo: Ática.

IBGE. (1990). Estatísticas históricas do Brasil. Séries Econômicas, Demográficas e Sociais de 1550 a 1988. . Rio de Janeiro: IBGE.

Läerne, C. F. (1885). Bresil et Java : rapport sur la culture du cafe en Amerique, Asie et Afrique. Haye: Martinus Nijhoff.

Lages, J. A. (1996). Ribeirão Preto: da Figueira à Barra do Retiro. Ribeirão Preto: VGA.

Luna, F. V. (set-dez de 1992). Características demográficas dos escravos de São Paulo (1777-1829). Estudos Econômicos, 22 (3), 443-483.

Luna, F. V. (jan-mar de 1998). São Paulo: População, Atividades e Posse de Escravos em Vinte e Cinco Localidades - (1777-1829). Estudos Econômicos, 28(1), 99-169.

Marcondes, R. L., \& Garavazo, J. (2002). A propriedade escrava e a hipótese de crescimento vegetativo em Batatais: a Classificação de Escravos (1875),. Anais do XIII Encontro Nacional de Estudos Populacionais. Ouro Preto.

Martins, R. V. (1998). Fazendas de São Simão. Pontal.

Milliet, S. (1938). Roteiro do Café. São Paulo.

Monbeig, P. (1998). Pioneiros e fazendeiros de São Paulo. São Paulo: Hucitec-Polis.

Müller, D. P. (1978). Ensaio d'um Quadro Estatístico da Província de São Paulo: ordenado pelas

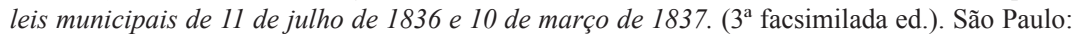
Governo do Estado.

Nozoe, N. H., \& Motta, J. F. (1999). Os produtores eventuais de café: nota sobre os primórdios da cafeicultura paulista (Bananal, 1799-1829). LOCUS: revista de história, 5, n. 1, 33-50.

Oliveira, F. P. (1975). Elementos para a história de São Simão. São Simão.

Oliveira, L. L. (1997). Economia e História. Franca - século XIX. Franca: UNESP-FHDSS/Amazonas S/A.

Oliveira, L. L. (2003). Ao lado do café: produção de exportação e de abastecimento do Franca. Faculdade de Filosofia, Letras e Ciências Humanas da Universidade de São Paulo, Departamento de História Econômica. São Paulo: (mimeo).

Petrone, M. T. (1968). A lavoura canavieira em São Paulo. São Paulo: Difusão Européia do Livro. 
Saes, F. d. (1981). As ferrovias de São Paulo (1870-1940). São Paulo: Hucitec/INL-MEC.

Saint-Hilaire, A. d. (1976). Viagem à Província de São Paulo. São Paulo: Martins.

Silva, B. d. (2008). As Estradas Paulistas: 1835-1870. Faculdade de Economia, Administração e Contabilidade da Universidade de São Paulo, Departamento de Economia. São Paulo: (mimeo).

Soares, L. d. (2003). No caminho dos Goiases: formação e desenvolvimento da economia escravista na Mogi-Mirim do século XIX. Faculdade de Filosofia, Letras e Ciências Humanas da Universidade de São Paulo, Departamento de História Social. São Paulo: (mimeo). 